theme 5

society

author(s) strand 2

design activism
Paula Pinto paulareaespinto@gmail.com

Universidade de Évora
Blucher Design Proceedings Dezembro de 2014, Número 5, Volume 1

\title{
Percursos de Sal and Interaç̧ões Artísticas com Cacela Velha: two public art projects through participatory design
}

This theoretical-practical investigation explores the arena of public art, focused on participatory design, which is sustained by an integrated view of the place. In this context, place is considered as an interaction between a set of human, biophysical, geographical, economic, political, historical, social, cultural and ecological conditions that characterize and determine, greatly, life in that place. This view focuses on a specificity of place that relates to the labor activities and natural resources manifest locally and, consequently, in the landscape.

The methodology used in this investigation is experimental in nature. The investigative artistic practice and, in particular, the methods used in the projects development were open, involving the local people in the realization of the project through an empathic approach of interaction design based on paradigms of listening and dialoguing.

The artistic projects were realized in peripherical places, which are strongly characterized by the relationships between the bodily subsistence of their population and the local natural resources.

The artistic practice developed crossed with the participatory design expanded the notion of place for artists and designers.

The aim of this active research was to analyze, test and interpret the evidence about the importance that place, considered in its multiple dimensions, can have in the conception and materializing of artistic interventions that interact with local populations, in a interaction and participatory design. It was also intended to test and evaluate the receptivity of the participant populations to the methodological characteristics of the realized projects.

participatory design, integrated perspective of place, public art, labor activities and natural resources

\section{Introduction}

The art projects I want to present here - Percursos de Sal and Interacções Artísticas com Cacela Velha - were based on two case-study that were part of practical research for my $\mathrm{PhD}$ thesis. Interacções Artísticas com Cacela Velha monitorized by the researcher. Both projects resulted from proposals presented to the municipalities of Castro Marim and Vila Real de Santo António in the years of 2001 and 2007, respectively. They included various art productions. The first was exhibited in 2003 in Castro Marim, the latter in 2009 in Cacela Velha.

Five main goals were at the work:

1. To demonstrate (through participatory and interactive design) the relevance of public 
art involving local populations actively;

2. To analize, test and interpret the evidence concerning the importance that place, understood in an integrated way, can have in the conception and materialization of art interventions in hybrid environments, both in urban and rural context, worked out with and for local communities and populations;

3. To test and assess the receptivity of the participant populations to the methodological characteristics of the projects;

4. To give public recognition to those involved and show off the value of their labor activities in a dignified form;

5. To encourage local populations to intervene in a more conscious way in the transformation of the places in which they live and work.

\section{Metodology and concepts}

The projects are in the domain of public art and centered in the so-called participatory and interactive design, sustained by an integrated perspective of the place, understood in its complexity - combining human, biophysical, geographical, economic, political, social, cultural, historical and ecological that largely characterize local life experiences.

The theme of the place is of special interest because the place is a way of learning about the relations local people establish among themselves and with their environment. The projects focused on the articulation between labor activities and local natural resources. They explored the everyday salt production, fishing activities and bivalve harvesting in the lagoon near the two villages. Moreover, it investigated the living narrative created by local inhabitants in that specific landscape.

The inclusion of 'place' as the main concept in the development of the aforementioned projects involved not only aesthetic assumptions inherent to any art endeavour, but also matters of ethics. Among these are the possible contribution to a public appreciation of neglected labor activities and of their importance as a way to promote these places and the role that these populations have in their production.

The concept of place-specific - term coined by the art critic Lucy Lippard in the 1990' is central to the projects Percursos de Sal and Interacções Artísticas com Cacela Velha. This concept was intended to refer to artistic practices based on living experience of space that go far beyond site-specific practices which only refer to physical and visual dimensions of space (geometric, geographic and architectural) (Lippard 1995: 54).

This art approach appeals to the concept of 'new genre public art' which appears for the first time in artist Suzanne Lacy's book (and art project) Mapping the terrain: new genre public art (1995). This branch of public art works with and for specific communities, and puts personal and local narratives above universal ones. Such art practices are the best form of public art, because the artist becomes an actor or facilitator working directly with real people, rather than dealing with an abstract public (Lacy 1995: 20).

Similarly, design activism refers to creative practices that engages political, social and environmental agency (Fuad-Luke 2009: 27). Normally, it distinguishes itself from commercial approaches embracing, marginal, or non-profit engaged design theories. His practitioner "...is a free agent; a non-aligned social broker and a catalyst; a co- creator and a happener" (Fuad-Luke 2009: xxi).

In these projects, I confronted myself with the various identities of both places. The multiple identities of a place are produced by those who use it. In the view of philosopher 
Henri Levebvre (1991) such production is related to the life experiences and the meanings assigned to a given place by its users. This concept of space has affinities with the idea of place I used in my work. For this reason, the relationship established between each of the inhabitants and the local natural resources through their labor has become the raw material I employed as artist and researcher.

Reflecting on the process and results of Percursos de Sal, I had the opportunity to redefine some of my initial concepts and ways of approaching local people, in order to develop an art practice closer to them and featuring them. In the case of the second project I believe those who participate were able to speak out through it.

\subsection{The interaction between artist and local population}

I valued the attitude of listening to others as expressed in the notion of 'enlightened listening' coined by the philosopher David Levin (1989: 223). This notion refers to the idea of the artist paying attention to the local populations and vice-versa. This kind of practices enable the inter-knowledge between both.

Hence, the projects involved small groups of local people (a group of children and local craftmen in the first and a group of children and old people in the second) in the process of knowing and doing, according to the participatory design methodology. Their role, initially as participants, switch afterwards, in the quality of observants, to the role of a public, when they came to the art installation premises and were confronted with the objects partially created by them.

During the phase of participation, I didn't assume, as artist, a leading role. The art work was decentralized and collective.

\subsection{The landscape as place}

In both projects I looked at the territory - and therefore to the landscape - as a manifestation of certain ways of living no longer popular and even marginalized to which the land and sea are crucial as natural resources. Such ways of living reflect the daily work routines of a community or group of people of a given place. As such, these routines are a form of knowledge. The idea of place corresponds to a space with history, memories, meanings and living experiences, understanding the landscape while revealing the living experiences of a space - the place.

\subsection{Projects description}

Strongly grounded on experience as a source of knowledge and on the interaction with the place and its inhabitants, the projects required relations of proximity and even intimacy with local people. Therefore, the research emphasized at every stage the methodologies of field work and interaction design, requiring relatively sojourns. The field work, besides being part of a participatory design methodology, functioned as art practice.

Percursos de Sal consisted in the construction of salt sculptures on the Sapal de Castro Marim, on a video installation and sculptures on salt, earth and vegetable fibers in the chapel. Interacções Artísticas com Cacela Velha was held in the space of the old cemetery, through an encounter-installation, articulating the interstitial spaces of the various media that the nature of the project required and the constant relational character.

1st phase - Acquaintance with Castro Marim and Cacela Velha through multi-sensorial experience, direct observation, participatory observation and a survey of the place through photographic, videographic and audio registrations. 
theme 5

society

Figure 1.

(2003), Percursos de Sal.

Figure 2.

(2009), Interacções Artísticas com Cacela Velha.

strand 2

design activism

2nd phase - Direct observation, interaction with local inhabitants and efforts to promote their interest in the project. I tried to get my intentions across, explaining that I would like to put together a project valuing the people whose lives have depended on the local natural resources. In the first project I talked several times with local people and specially with salt producers about their life experiences. Later, tests were carried out to the behavior and resistance of salt. Concerning the second project it was encouraged the involvement of local people. Several meetings with fishermen and bivalve harversters took place. There are audio registrations and footage of these meetings. They fueled the whole creative process. People were invited to participate. They were asked to choose an object representing a personal connection with Cacela Velha.

3rd phase - Construction of the final pieces. In the first project sculptures were made with the collaboration of artisans, children and local people (Fig. 1). In the second project the recording of people's personal narratives and the photos of their objects were completed (Fig. 2). All of these were examples of participatory design. These tasks required meetings with each one of the nine local participants. According to the anthropologist Daniel Bertaux (1997: 94):

\footnotetext{
"Biographical accounts make visible the social element in its multiple sides rather than being a mere reflex of disconnected abstract structures - the social element emerges as an armour made of living experiences."
}

4th phase - Installation exhibition period. In relation to Percursos de Sal this stage culminated in an homage to salicultors and local artisans. It was performed during the opening of the exhibition, in the local chapel, through a symbolic act - the delivery of "bread of salt", by the local children, to the referred people. The following year proceeded to a second integrated approach to place which consisted in the replacement of the salt on the stilt structures (Fig. 3) of the preceding sculptures. This was done by a group of locals. In the second project, besides the video-installation with the accounts of local fishermen about their labour activities, nine photos in light boxes were exhibited at the same spot. Each photo represented an object selected by each of the local participants. The
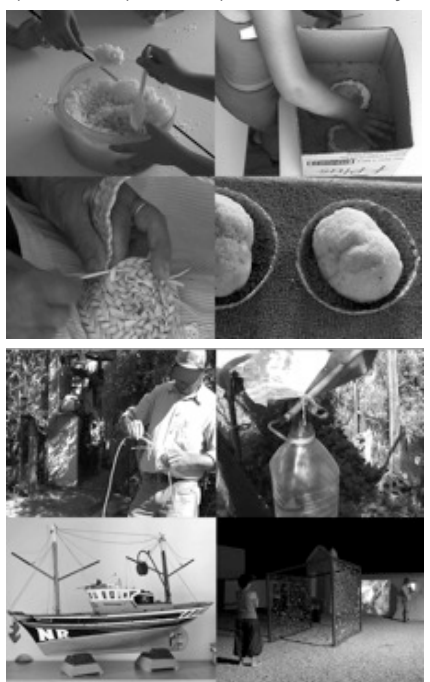


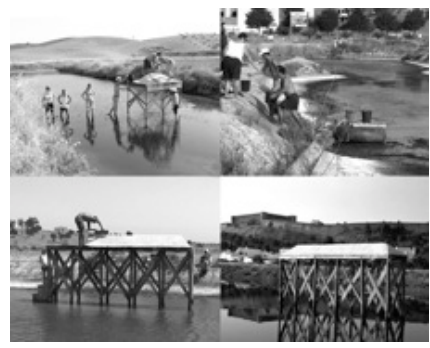

distinguishing aspect of each object were the stories behind them, narrated by their owners. The narrations could be listened through headphones located sideways. According to relational practices, the produced objects in both projects resulted from the interaction with people in its relation with place and not from an "assertion of an independent and private symbolic space" (Borriaud 2002: 19).

\subsection{Evaluation of the project}

The last project is a monitorized case-study, whose results were evaluated at three levels: by a focus group of local people, by the population in general visiting the art installation, and by a pannel of experts: An art gallery director, USA; an artist, USA; an artist, GB; an designer, POR; a member of the Association for the Rehabilitation and Research of the Natural and Cultural Patrimony of Cacela Velha, POR. They were considered experts because their activity is focused on theme.

The focus group was confronted with a semi-structured questionnaire and did an interview that took place at their habitual whereabouts; the population in general was asked also to answer to a semi-structured questionnaire; the experts were interviewed through a previously arranged questionnaire.

During the exhibition there were leaflets around explaining the intentions of the project. The questionnaires to the general visitor were likewise available. I often addressed visitors explaining the concept of the project. The contentment of the participants manifested in the several comebacks to the premises of the exhibition and in their comments.

\section{Conclusion}

The projects were seen by participants and mere observers as conveying a form of art intrinsically connected to the real lives of the people involved and to those factors that give shape to them (human, biophysical, geographical, economic, political, social, cultural, historical and ecological); the art practice in question required multi-sensorial interactions, opposed to the exclusive visual paradigm so typical of the western tradition.

The collaboration of local people, as well as the valorization of their life experiences, promoted their self-esteem and improved their inclusion in the community. The work process resulted also in strong personal bonds and a feeling of complicity between artist and participants. 
Another important conclusion is that it makes sense to extend art to nonspecialized publics, involving them in art projects actively, through emphatic and participatory approaches. It's of extreme importance to listen to the other and allow his or her point of view to ressonate through the art work in a dignified form. All this means to replace the subjectivity of the artist, typical of conventional modern art, by the intersubjectivity implied in the interaction between artist and participant local people.

The adoption of an integrated view of place promotes sharing life experiences as conditions to put forward a form of public art based on the combined knowledge of all those involved. This community-based public art form reconnects the local population to its labour activities through artist and community interaction in the context of participatory design, using a comprehensive understanding of life experiences with the local population.

\section{References}

Bertaux apud Casal (1997) 'Suportes teóricos e epistemológicos do método biográfico', in Trabalho de Campo, Ethnologia, nova série, nº 6-8, p. 94. Lisboa:Edições Cosmos. Borriaud, Nicolas (1998) Esthétique Relationnelle, Dijon, France: Les Presses du Reel. Lacy, Suzanne (1995) 'Cultural Pilgrimages and Metaphoric Journeys', in Lacy, S. (ed.). Mapping the Terrain. New Genre Public Art, Washington: Bay Press: pp. 19-47. Lefebvre, Henri (1991) The Production of Space, Oxford: Blackwell Publishers. Levin, David (1989) The Listening-Self: Personal Growth, Social Change and the Closure of Metaphisics, Minnesota: Routledge.

Lippard, Lucy (1995) Notes from a Recent Arrival, in Doherty, C. (ed.) Situation: Documents of Contemporary Art. London: Whitechapel, The Mit Press. Luke, Alastair (2009) Design Activism: Beautiful Strangeness for a Sustainable World. London: Earthscan. 
